\title{
MASALAH KESETARAAN DALAM PENDIDIKAN MATEMATIKA
}

\author{
Hendra Irawan \\ Institut Ilmu Sosial Dan Manajemen Stiami \\ Email: hendra01@gmail.com
}

\begin{abstract}
Abstrak
Makalah ini membahas kesetaraan dalam pendidikan matematika dalam kaitannya dengan akses oleh semua siswa ke peluang untuk terlibat dalam matematika yang kaya. Agar bangsa mana pun dapat berkembang secara teknologi, harus ada pendidikan besar-besaran dari penduduknya dalam matematika tanpa memandang ras, status sosial, status kesehatan, jenis kelamin, atau variabel diskriminatif atau klasifikasi lainnya. Di seluruh dunia, pembangunan tidak terbatas pada beberapa individu. Itu adalah tanggung jawab kolektif. Pendidikan dianggap sebagai instrumen untuk segala bentuk perkembangan. Makalah ini membahas Keluarga, Jenis Kelamin, Status Sosial, Prestasi, Penghasilan, Status Kesehatan dan Partisipasi Politik di antara faktor-faktor lain yang dapat mempengaruhi masalah ekuitas dalam pendidikan matematika. Ketimpangan dalam pendidikan berdampak negatif terhadap mobilitas sosial warga negara. Diantara anjuran untuk mencapai pemerataan dalam pendidikan matematika adalah keadilan dan inklusi. Sistem desain pendidikan, praktik dan bagaimana sumber daya dialokasikan harus menjamin kesetaraan sebanyak mungkin.

Kata kunci: Pendidikan Matematika
\end{abstract}

\begin{abstract}
The paper discussed equity in mathematics education in relation to access by all students to opportunities to engage in rich mathematics. For any nation to develop technologically there must be massive education of the populace in mathematics irrespective of race, social status, health status, sex or any other discriminative or classification variables. The world over, development is not limited to a few individual. It is a collective responsibility. Education is regarded as an instrument for any form of development. The paper discussed Family, Gender, Social Status, Achievements, Earnings, Health status and Political participation among other factors that can affect equity issues in mathematics education. Inequity in education affects social mobility of citizenry negatively. Among the recommendation to achieve equity in mathematics education is fairness and inclusion. The educational design system, practices and how resources are allocated should ensure equity as much as possible.
\end{abstract}

Keywords: Mathematics Education

\section{A. PENDAHULUAN}

Pendidikan sains, teknologi dan matematika (STME) telah mempercepat laju perubahan di dunia. Itu telah memberikan dasar untuk kekayaan dan perkembangan dan membawa peningkatan besar pada kualitas hidup. Model sains dalam menafsirkan alam dan perkembangan teori semuanya mengandalkan matematika. JURNAL PAPATUNG: Vol. 2 No. 1 Tahun 2019 ISSN: 2715-0186 
Konversi selanjutnya dari interpretasi dan teori ini menggunakan teknologi untuk menemukan hal-hal untuk kenyamanan dan manfaat manusia untuk memperluas kemampuan dan kapasitasnya untuk memanipulasi dan mengendalikan lingkungannya juga menerapkan matematika. Matematika merupakan alat penting untuk perkembangan ilmu pengetahuan dan teknologi. Oleh karena itu, pentingnya dan tempat non-pengganti pendidikan matematika, tidak bisa terlalu ditekankan.

Untuk setiap bangsa untuk berkembang secara teknologi harus ada pendidikan besar-besaran penduduk dalam matematika terlepas dari ras, status sosial, status kesehatan, jenis kelamin atau variabel diskriminatif atau klasifikasi lainnya (Nsofor, 2008). Ketimpangan pendidikan adalah perbedaan hasil belajar atau prestasi yang dialami siswa yang tergolong berbeda berdasarkan variabel tertentu. Prestasi pendidikan sebagian besar waktu diukur menggunakan skor atau nilai numerik. Nilainya bisa berupa Grade Point Average (IPK). Skor tersebut dapat menguji skor dalam tes kelas atau bentuk ujian lainnya. Prestasi ketidaksetaraan pendidikan dikaitkan dengan beberapa variabel. Variabel ini termasuk keluarga asal, jenis kelamin, dan kelas sosial. Variabelnya tidak sama di semua tempat. Ini dapat mencakup pencapaian, pendapatan, status kesehatan, dan partisipasi politik di beberapa tempat (Ferreria dan Gignoux, 2014). Banyak ketidaksetaraan pendidikan dikaitkan dengan ketimpangan ekonomi. Di beberapa negara multiras, perbedaan ekonomi dan sosial terjadi karena garis ras. Lokasi tempat tinggal dan bahasa juga menjadi faktor penyebab ketimpangan prestasi pendidikan (Lee dan Gary, 2005). Di seluruh dunia, ada upaya terus menerus untuk mereformasi pendidikan di semua tingkatan. Upaya reformasi ini bergantung pada banyak kekuatan. Kekuatannya bisa berupa sejarah, harapan masyarakat dari lulusan tingkat pendidikan tertentu, perubahan budaya, dan perkembangan ekonomi atau teknologi. Ketimpangan masih ada. Pendidikan memajukan masyarakat. Ini mempromosikan produksi warga negara yang baik, identitas, kesetaraan kesempatan dan inklusi sosial, kohesi sosial JURNAL PAPATUNG: Vol. 2 No. 1 Tahun 2019 
serta pertumbuhan ekonomi dan pekerjaan "dan untuk alasan ini, kesetaraan harus dipromosikan (Shrivastava dan Shrivastava, 2014). Kesetaraan dalam pendidikan matematika terkait dengan akses oleh semua siswa ke peluang untuk terlibat dalam matematika yang kaya. Pengetahuan matematika yang rapuh akan mempengaruhi pembelajaran dan kesenangan matematika siswa. Keluarga, Jenis Kelamin, Status Sosial, Prestasi, Penghasilan, Status Kesehatan dan Partisipasi Politik adalah beberapa faktor lain yang dapat mempengaruhi masalah pemerataan dalam pendidikan matematika.

\section{B. PEMBAHASAN}

Latar belakang keluarga telah diidentifikasi sebagai faktor yang paling berpengaruh dalam prestasi siswa. Lee dan Gary (2005), menemukan bahwa ada hubungan antara prestasi akademik orang tua dengan prestasi akademik anak mereka. Studi ini mengungkapkan bahwa sementara $11 \%$ siswa dari peringkat pendidikan kelima terbawah pencapaian akademis orang tua memperoleh gelar sarjana, $80 \%$ siswa dari lima puluh teratas peringkat pendidikan orang tua memperoleh gelar akademis (Haskins dan James, 2009). ). Siswa dari lima orang tua teratas mungkin memiliki rumah yang lebih mendukung keberhasilan pendidikan. Lebih banyak buku, perpustakaan, bantuan dari rumah dan percakapan intensif intelektual akan lebih tersedia bagi anak-anak dari jenis rumah ini. Siswa dari kelas lima terbawah mungkin tidak memiliki akses ke fasilitas, lingkungan dan situasi seperti itu. Mereka mungkin kurang tertinggal dalam memori verbal, kosakata, matematika, prestasi membaca dan bahkan memiliki lebih banyak masalah perilaku (Farkas, 2006). Keluarga di kelas menengah ke atas mungkin memiliki koneksi yang akan membantu anak-anak mereka diterima di sekolah yang tepat. Stres yang dialami anak-anak dari keluarga kelas bawah mungkin tidak memungkinkan mereka memiliki aspirasi akademik yang tinggi yang dapat mempengaruhi pertumbuhan JURNAL PAPATUNG: Vol. 2 No. 1 Tahun 2019 
akademik mereka (Gamoran, 2001). Sementara siswa dari kelas bawah mungkin mendapatkan istirahat total dari studi mereka selama liburan, mungkin tidak demikian untuk siswa dari kelas menengah ke atas. Efek yang dihasilkan adalah hilangnya skill selama periode ini. Siswa dari rumah orang tua tunggal mungkin menderita beberapa perhatian yang diperlukan daripada rekan mereka dari dua orang tua. Sumber daya yang lebih sedikit, perhatian orang tua yang lebih sedikit, dan stres yang lebih tinggi semuanya berpengaruh pada prestasi akademik siswa (Farkars, 2006).

Pengaruh lain dari latar belakang keluarga terhadap prestasi pendidikan adalah di bidang pengetahuan dan persepsi budaya. Kebudayaan, meliputi pengetahuan, kepercayaan, seni, moral, hukum, adat istiadat, dan kemampuan serta kebiasaan lain yang diperoleh oleh anggota masyarakat. Oleh karena itu, upaya untuk mempersiapkan mereka, bertahan hidup dan hidup sejahtera. Apa yang sangat relevan di sini dan yang muncul, adalah bahwa budaya adalah "cara hidup" orangorang yang ditularkan ke generasi berikutnya. Nigeria terdiri dari sejumlah besar entitas budaya; ia memiliki kumpulan norma, tugas peran dan ketertiban yang memungkinkan keberadaan masyarakat (Ajewole, 2006). Bahasa yang digunakan dalam keluarga juga dapat menyebabkan ketimpangan pendidikan di kalangan siswa. Jika orang tua tidak memahami bahasa pengantar di sekolah, berarti siswa tidak akan bisa mendapatkan bantuan di rumah untuk mempermudah proses pembelajarannya. Bahasa yang digunakan di rumah sama dengan yang digunakan sebagai bahasa pengantar di sekolah membuat pemahaman siswa lebih mudah. Jenis kelamin Dalam budaya tradisional Nigeria, praktiknya adalah bahwa tempat wanita dianggap sebagai yang utama di rumah. Tujuan utamanya adalah agar wanita tinggal di rumah dan menjadi ibu dan istri yang baik. Keluarga dengan peringkat ekonomi rendah lebih suka menginvestasikan sumber daya mereka yang terbatas untuk pendidikan anak laki-laki daripada anak perempuan yang pada akhirnya mungkin JURNAL PAPATUNG: Vol. 2 No. 1 Tahun 2019 
menikah dengan keluarga lain atau meninggalkan profesi mereka. Masih terdapat stereotipe budaya dan sosial tentang "profesi bagi perempuan" yang sangat mempengaruhi pilihan bidang studi mereka. Ada beberapa peran tradisional yang diberikan kepada laki-laki dan perempuan, misalnya untuk perempuan; perawat, mengajar dan memasak, dan untuk pria; sains, teknik, perburuan (Ajewole, 2006). Analisis kritis terhadap peran dan tugas ini menunjukkan bahwa tidak ada kualitas khusus yang menjamin beberapa dari mereka ditugaskan secara eksklusif kepada pria atau wanita. Sosialisasi peran gender berdampak pada akses perempuan terhadap pendidikan. Di Nigeria, orang tua mensosialisasikan anak mereka ke dalam peran tertentu berdasarkan gender. Laki-laki lebih disukai dan didorong untuk terlibat dalam komputer dan pembelajaran ilmiah. Betina didorong untuk mempelajari keterampilan domestik.

Sebuah studi oleh Banks (2013), melaporkan bahwa gender tidak berpengaruh signifikan terhadap matematika dan prestasi belajar di tahun-tahun awal sekolah. Namun penelitian tersebut menemukan bahwa anak laki-laki mendapat nilai lebih tinggi pada matematika tingkat lanjut, dan lebih berpartisipasi dalam diskusi kelas daripada anak perempuan. Bolarin (2004) menyesalkan rendahnya partisipasi perempuan dalam Sains, Teknologi dan Pendidikan Matematika dapat ditelusuri kembali ke dua tahun terakhir pendidikan menengah. Beberapa penelitian mendukung hal ini, di antaranya penelitian Bajah \& Bozimo (2005) tentang distribusi pendaftaran siswa laki-laki dan perempuan dalam mata pelajaran IPA dan Matematika di tingkat sekolah menengah.

\section{STATUS SOSIAL}

Status sosial orang tua berkontribusi pada ketimpangan akses siswa ke pendidikan. Siswa dari orang tua di kelas atas atau menengah memiliki kesempatan lebih baik untuk dicap sebagai anak berbakat daripada siswa dari kelas rendah JURNAL PAPATUNG: Vol. 2 No. 1 Tahun 2019 
bahkan dengan tingkat potensi yang sama. Alasannya bisa dijelaskan berdasarkan cara pemilihan. Dalam mengidentifikasi dan memilih siswa, penggunaan tes standar biasanya digunakan. Beberapa tes standarisasi mungkin memiliki budaya dan penguasaan bahasa bawaan. Siswa dari orang tua kelas rendah mungkin tidak memiliki akses ke informasi yang diperlukan dan kemahiran tinggi yang diminta oleh tes standar. Jika sistem nominasi digunakan, nominator mungkin tidak memiliki pelatihan dalam mengidentifikasi siswa berbakat. Pengetahuan orang tua, keterampilan politik dan kekuasaan yang menuntut sekolah untuk mengklasifikasikan anaknya sebagai anak berbakat atau berbakat merupakan faktor yang dapat menyebabkan ketimpangan dalam pendidikan (Banks, 2013).

Pendidikan memainkan peran kunci dalam menentukan bagaimana Anda menghabiskan kehidupan dewasa Anda - tingkat pendidikan yang lebih tinggi berarti penghasilan yang lebih tinggi, kesehatan yang lebih baik, dan umur yang lebih panjang. Dengan cara yang sama, biaya sosial dan finansial jangka panjang dari kegagalan pendidikan tinggi. Mereka yang tidak memiliki keterampilan untuk berpartisipasi secara sosial dan ekonomi menghasilkan biaya yang lebih tinggi untuk kesehatan, dukungan pendapatan, kesejahteraan anak dan sistem jaminan sosial.

Jadi, sistem yang adil dan inklusif yang membuat manfaat pendidikan tersedia bagi semua adalah salah satu langkah dan strategi paling ampuh untuk membuat masyarakat lebih adil. Harapan bahwa perluasan pendidikan secara otomatis akan mewujudkan masyarakat yang lebih adil hanya sebagian terwujud. Perempuan telah membuat kemajuan dramatis, tetapi mobilitas sosial secara keseluruhan tidak meningkat dan di beberapa tempat ketimpangan pendapatan dan kekayaan meningkat. Pendidikan yang adil dan inklusif untuk mayoritas dan minoritas adalah cara yang mungkin untuk mengatasi tantangan ini. Kesetaraan dalam pendidikan meningkatkan kohesi sosial dan kepercayaan. 


\section{PRESTASI}

Struktur dasar sistem pendidikan mempengaruhi kesetaraan. Secara tradisional, sistem pendidikan memisahkan atau menggolongkan siswa menurut pencapaian pendidikan. Bukti dari studi sekolah menengah dan dasar menunjukkan bahwa klasifikasi atau segregasi tersebut dapat meningkatkan ketimpangan dan ketimpangan, terutama jika itu terjadi di awal proses pendidikan. Penyortiran awal juga dapat melemahkan hasil secara keseluruhan. Memilih siswa berdasarkan prestasi akademik cenderung menciptakan perbedaan sosial yang besar antar sekolah. Ini juga meningkatkan hubungan antara status sosial-ekonomi dan kinerja - itu cenderung untuk mempercepat kemajuan orang-orang yang telah memperoleh awal terbaik dalam hidup dari orang tua mereka - dan juga terkait dengan kinerja yang lebih kuat pada skala teratas dalam matematika dan sains. Jadi seleksi akademis perlu digunakan dengan hati-hati karena resiko yang ditimbulkannya terhadap ekuitas.

\section{PENDAPATAN}

Struktur sosio-ekonomi sistem pendidikan juga penting. Sistem sekolah menengah di mana terdapat perbedaan sosio-ekonomi yang besar antar sekolah cenderung rata-rata memiliki hasil yang lebih buruk dalam matematika dan membaca dan penyebaran hasil membaca yang lebih besar. Memang, latar belakang sosial lebih merupakan penghalang bagi keberhasilan pendidikan daripada dalam sistem tanpa perbedaan sosio-ekonomi antar sekolah. Pemerintah seringkali mengizinkan orang tua memilih sekolah, sebagian untuk kepentingan kesetaraan. Tetapi ini sebenarnya dapat meningkatkan risiko ketidaksetaraan karena orang tua yang lebih berpendidikan membuat pilihan yang lebih tepat. Di banyak negara organisasi untuk Kerja Sama dan Pembangunan Ekonomi (OECD), pilihan yang lebih banyak dalam sistem sekolah dikaitkan dengan perbedaan yang lebih besar dalam komposisi sosial sekolah.

JURNAL PAPATUNG: Vol. 2 No. 1 Tahun 2019

ISSN: 2715-0186 
Kesimpulannya adalah bahwa pilihan sekolah memerlukan pengelolaan yang cermat untuk membentuk perspektif kesetaraan, terutama untuk memastikan bahwa hal itu tidak mengakibatkan peningkatan perbedaan dalam komposisi sosial sekolah. Sekolah populer cenderung kelebihan jumlah pelanggan, dan membutuhkan cara untuk memastikan perpaduan sosial yang merata. Ini dapat mencakup metode pemilihan seperti pengaturan lotere. Premi keuangan untuk sekolah yang menarik siswa yang kurang beruntung juga dapat membantu. Apa yang terjadi di dalam kelas jelas mempengaruhi kesetaraan, tetapi hubungan antara sekolah, orang tua, dan masyarakat juga penting. Pembelajaran siswa mendapat manfaat dari hubungan sekolah-rumah yang efektif, tetapi dukungan yang lemah di rumah dapat menahan anak-anak dari latar belakang yang kurang mampu.

Kesempatan kedua bagi mereka yang tidak memiliki pendidikan dasar dan keterampilan dapat diberikan dalam berbagai cara, termasuk program yang memberikan pelatihan keaksaraan, program berbasis kerja, dan pengaturan untuk mengenali pembelajaran informal. Di Amerika Serikat, hampir 60\% putus sekolah akhirnya mendapatkan kredensial sekolah menengah (sertifikat GED) melalui program pendidikan kesempatan kedua.

Membuat siswa mengulang satu tahun jika mereka tidak mengikuti adalah pilihan yang populer; di beberapa sistem sekolah, dan ada sedikit bukti bahwa anakanak mendapat manfaat darinya. Tingkat pengulangan tahun yang tinggi di beberapa negara perlu dikurangi dengan mendorong pendekatan alternatif di kelas. Hal ini dimungkinkan untuk meningkatkan pencapaian kelas dengan metode seperti penilaian formatif - proses memberikan kembali informasi tentang kinerja kepada siswa dan guru dan menyesuaikan serta meningkatkan pengajaran dan pembelajaran sebagai tanggapan, terutama dengan siswa yang berisiko. Strategi "Membaca 
pemulihan" - intervensi intensif jangka pendek dari pelajaran satu lawan satu - dapat membantu banyak pembaca yang miskin untuk mengejar ketinggalan.

Agar intervensi kelas berhasil, bagaimanapun, guru membutuhkan dukungan untuk mengembangkan teknik mereka untuk membantu siswa yang tertinggal. Cacat fisik anak-anak dan juga mereka yang mengalami keterbelakangan mental dibedakan dalam sistem pendidikan dan dinding institusi. Kebutuhan individu membuat mereka secara otomatis terisolasi dari teman sebaya dan manfaat dari pendidikan umum. Garis / hambatan politik juga menyebabkan ketimpangan akses pendidikan. Sekolah seharusnya menerima sumber daya yang sama tetapi tidak diragukan lagi ada ketimpangan. Kasus perguruan tinggi pemerintah federal atau sekolah persatuan dan beberapa sekolah khusus di Nigeria segera terlintas dalam pikiran.

Ketimpangan ini mempengaruhi mobilitas sosial (kemampuan untuk naik tanpa memandang latar belakang). Sistem pendidikan bertingkat memaksa keluarga berpenghasilan rendah untuk menempatkan anak-anak mereka ke sekolah yang kurang ideal yang tidak memiliki kesempatan dan motivasi pendidikan yang sama seperti di mana keluarga berpenghasilan tinggi menyekolahkan anak mereka (Leonhardt, dan Scott, 2005). Kesetaraan dalam pendidikan memiliki keadilan dan inklusi sebagai dua dimensi utama. Tiga bidang kebijakan utama dapat memengaruhi kesetaraan dalam pendidikan: desain sistem pendidikan, praktik di dalam dan di luar sekolah, dan bagaimana sumber daya dialokasikan. Kemitraan Global Pendidikan (GPE) berfungsi untuk menciptakan upaya global untuk mengurangi ketimpangan pendidikan dengan fokus pada negara-negara termiskin. GPE adalah satu-satunya upaya internasional dengan fokus khusus mereka dalam mendukung upaya negaranegara untuk mendidik kaum muda mereka dari pendidikan dasar hingga menengah. Tujuan utama kemitraan ini termasuk menyediakan akses pendidikan bagi setiap anak, mengasuransikan setiap anak menguasai keterampilan dasar berhitung dan melek huruf, meningkatkan kemampuan pemerintah untuk menyediakan JURNAL PAPATUNG: Vol. 2 No. 1 Tahun 2019 
pendidikan berkualitas bagi semua, dan menyediakan ruang yang aman bagi semua anak untuk belajar. Mereka adalah a kemitraan antara donor dan negara berkembang tetapi negara berkembang membentuk strategi pendidikan mereka sendiri berdasarkan prioritas pribadi mereka. Menurut Banks, pendidikan multikultural adalah gerakan reformasi yang memungkinkan semua siswa memperoleh kesempatan yang sama untuk belajar tanpa memandang jenis kelamin, kelas sosial, orientasi seksual, etnis, atau budaya mereka (Banks dan Cherry, 2009). Karena persaingan dan bias tidak dapat dihindari dalam lingkungan sekolah, kesetaraan pendidikan merupakan cita-cita yang tidak dapat sepenuhnya dicapai.

\section{KESIMPULAN}

Berikut ini dapat membantu dalam pemberian pemerataan dalam pendidikan matematika kepada siswa. Salah satu cara untuk meningkatkan kinerja dan mencegah putus sekolah adalah dengan mengidentifikasi siswa yang berisiko sejak dini dan mengambil tindakan dengan cepat. Ini berarti memantau informasi tentang kehadiran, kinerja dan keterlibatan dalam kegiatan sekolah, dan memiliki tanggapan konkret untuk meningkatkan hasil dan mencegah putus sekolah. Pendidikan menengah atas harus menarik tidak hanya bagi kalangan elit yang cenderung akademis, tetapi juga untuk menawarkan jalur berkualitas baik tanpa jalan buntu dan hubungan yang efektif dengan dunia kerja. Menawarkan bimbingan karir dan konseling yang baik kepada siswa berisiko, serta membuat kurikulum lebih fleksibel dan beragam sangat membantu. Dukungan pembelajaran tambahan di akhir sekolah menengah juga dapat membantu mendorong siswa untuk tetap bersekolah.

Banyak negara dapat dengan bermanfaat mengikuti pendekatan Finlandia untuk kesulitan belajar, yang menawarkan serangkaian intervensi intensif untuk menarik kembali mereka yang tertinggal ke arus utama. Tampaknya berhasil: hanya 1\% dari anak Finlandia berusia 15 tahun tidak dapat menunjukkan keterampilan JURNAL PAPATUNG: Vol. 2 No. 1 Tahun 2019 
membaca fungsional dasar, sedangkan rata-rata OECD adalah 7\%. Harus ada penekanan lebih pada penggunaan teknologi komunikasi untuk tujuan instruksional untuk melengkapi metode pembelajaran tradisional. Ini akan memungkinkan pelajar memiliki akses ke instruksi dari para ahli melalui berbagi konten, video dan forum online. Ada kebutuhan untuk membantu guru mengembangkan teknik mereka untuk membantu siswa yang tertinggal. Pencapaian kelas dapat ditingkatkan dengan menggunakan metode penilaian formatif. Jika stratifikasi peserta didik akan dilakukan harus ada pembenaran berdasarkan manfaat yang terbukti. Hal itu bisa dilakukan untuk membantu meningkatkan prestasi dan siswa berisiko mencegah putus sekolah. Pemilihan murid untuk sekolah hendaknya tidak semata-mata sebagai fungsi prestasi. Hal ini dikarenakan status sosial ekonomi dan prestasi saling berkaitan, dimana anak dari keluarga sosial ekonomi tinggi mendapatkan awal yang lebih baik dari orang tuanya. Guru dan orang tua harus bekerja sama untuk saling melengkapi, dan menciptakan ruang bagi keterlibatan orang tua dalam kurikulum mungkin tidak pada tempatnya. Para orang tua harus meningkatkan percakapan mereka dengan anak-anak mereka tentang sekolah mereka. Kebijakan pemerintah yang jelas tentang tingkat keterlibatan yang diharapkan dari orang tua harus diterapkan. Jika ada pendidikan gratis, orang tua harus diberi tahu bahwa ada tanggung jawab keuangan lainnya. Orang tua harus dididik tentang perlunya mengubah sikap mereka dan berinvestasi dalam pendidikan anak perempuan mereka di bidang sains, teknologi, dan matematika.

Ajaran budaya dan agama yang anti perempuan dalam pendidikan secara umum dan anti perempuan dalam pendidikan sains pada khususnya perlu dicegah. Masalah kesehatan didasarkan pada sains. Temuan penelitian menunjukkan bahwa banyak masalah kesehatan di negara berkembang seperti tingginya angka kematian bayi dan materi, angka infertilitas yang tinggi, malnutrisi dan kondisi stres dll berkorelasi positif dengan rendahnya tingkat perempuan dalam sains. 


\section{DAFTAR PUSTAKA}

Ajewole, G.A. (2006). Ilmu Pengajaran untuk Kesetaraan Gender di bawah Program Pendidikan Dasar Universal (UBE). Makalah dipresentasikan pada konferensi Nasional yang diselenggarakan oleh Akademi Pendidikan Nigeria Universitas Benin 6-10 November.

Bajah, S.T. dan Bozimo, H. (2005). Partisipasi rendah anak perempuan dalam pendidikan STM: strategi untuk ganti rugi. Mempromosikan Sains, Teknologi, dan Matematika di antara Girls \& Women di Nigeria. Publikasi cabang pendidikan wanita F.M.E.

Banks, James (2013). “1”. Pendidikan Multikultural: Masalah dan Perspektif. John Wiley \& Sons.

Bank, James; eds, Cherry (2009). Pendidikan Multikultural: Masalah dan Perspektif. John Wiley \& Sons.

Bolarin, T.A. (2004). Masalah dan Prospek area wanita untuk studi ilmiah dan Pelatihan Teknologi di tingkat Universitas: Studi kasus di Negara Bagian Lagos. Jurnal Pendidikan Afrika 1. (1).

Farkas, George (2006). "Bagaimana Ketimpangan Pendidikan Berkembang”. Pusat Kemiskinan Nasional. Seri Kertas Kerja: 1-50.

Ferreira, Francisco; Gignoux, Jeremie (2014). "Pengukuran Ketimpangan Pendidikan:

Prestasi dan Peluang ”. Tinjauan Ekonomi Bank Dunia 28 (2): 210-246.

Gamoran, Adam (2001). "Persekolahan Amerika dan Ketimpangan Pendidikan: Perkiraan untuk Tanggal 21

Abad". Sosiologi Pendidikan 74: 135-153.

Haskins, Ron; James Kemple (2009). "Sasaran Baru untuk Sekolah Menengah Amerika: Perguruan Tinggi

Persiapan untuk Semua ". Masa Depan Anak-Anak 19: 1-7.

Haycock, Kafi (2001). "Menutup Celah Prestasi”. Membantu Semua Siswa Mencapai 58: 611. Ifenkwe, G.E. (2013). Perkembangan pendidikan di Nigeria: Tantangan dan prospek di abad ke-21. Jurnal Universal Pendidikan dan Studi Umum. 2 (1). 7 - 14.

Lee, Chungmei; Gary Orfield (2005). "Mengapa Segregasi Penting: Kemiskinan dan Pendidikan

Ketidaksamaan". Proyek Hak Sipil. Universitas Harvard: 1-47.

JURNAL PAPATUNG: Vol. 2 No. 1 Tahun 2019

ISSN: 2715-0186 